\title{
Yellow nail syndrome associated with rheumatoid arthritis, thiol-compound therapy and early gastric cancer
}

\author{
Hirofumi Taki, Kazuyuki Tobe
}

First Department of Internal Medicine, University of Toyama, Toyama, Toyama, Japan

Correspondence to Dr Hirofumi Taki, htaki-tym@umin.ac.jp

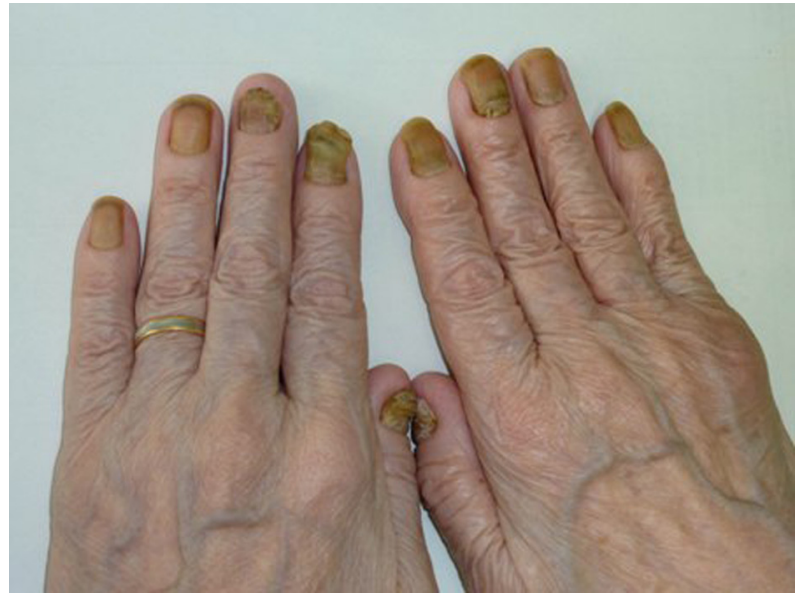

Figure 1 Yellowish discolouration of the fingernails.

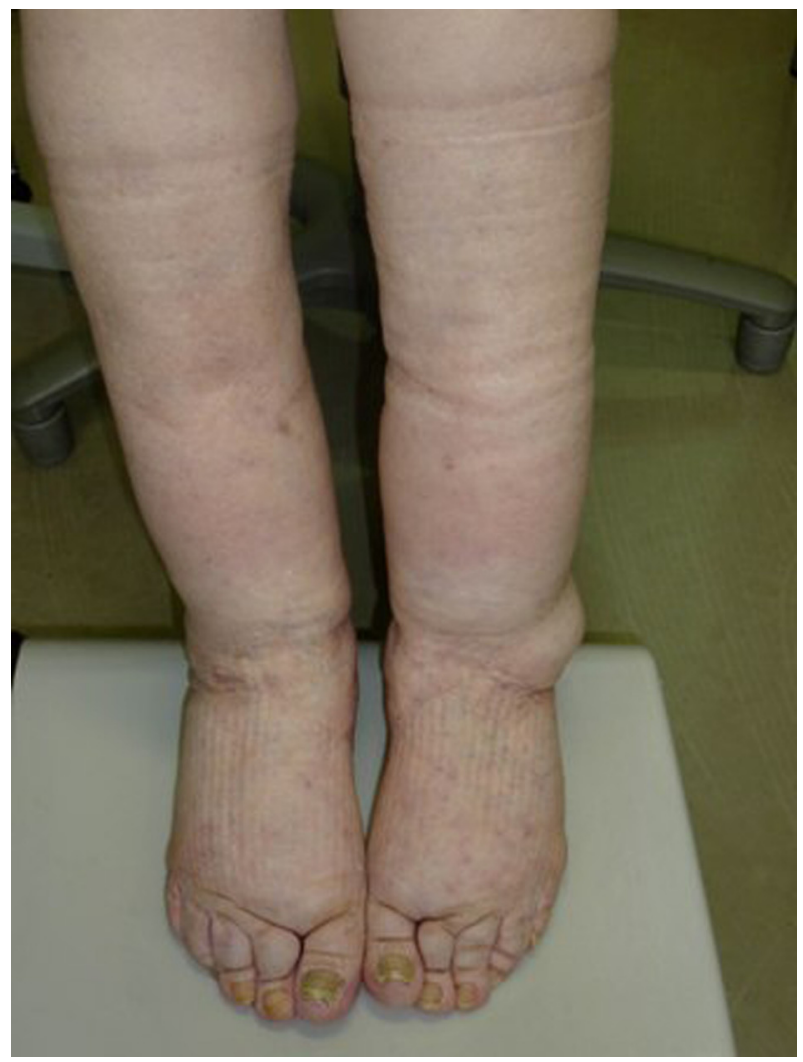

Figure 2 Lymphoedema of the legs and yellowish discolouration of the toenails.

\section{DESCRIPTION}

Yellow nail syndrome (YNS) was first described in 1964 by Samman and White, who noted the association of nail discolouration and leg oedema. ${ }^{1}$ Emerson added pleural effusion as the third element of YNS. ${ }^{2}$ Hiller et al reported that the respiratory manifestations are diverse and include pleural effusion, bronchiectasis, rhinosinusitis, chronic cough and recurrent lung infections. ${ }^{3} \mathrm{He}$ also reported that the presence of two of three elements, namely yellow nails, lymphoedema and one the aforementioned respiratory manifestations, has been judged sufficient for diagnosis. ${ }^{3}$ Males and females are equally affected and typically present between the fourth and sixth decades of life. ${ }^{4}$ In the present case, bronchiectasis preceded the appearance of yellow nails (figure 1) and lymphoedema of the legs (figure 2). The triad of yellow nails, lymphoedema and lung involvement is present in only a quarter of patients with YNS. Furthermore, all three criteria are present in $40 \%$ to $60 \%$ of patients with YNS. ${ }^{4}$ The most common conditions associated with YNS include malignancies, connective tissue diseases, endocrine disorders and drugs, including thiol compounds. ${ }^{4}$ The present patient had three conditions, namely rheumatoid arthritis, ${ }^{5}$ thiol-compound therapy and early gastric cancer. The thiol compound was withdrawn, and endoscopic segment dissection of the gastric cancer was performed, resulting in resolution of the yellow nails (figure 3).

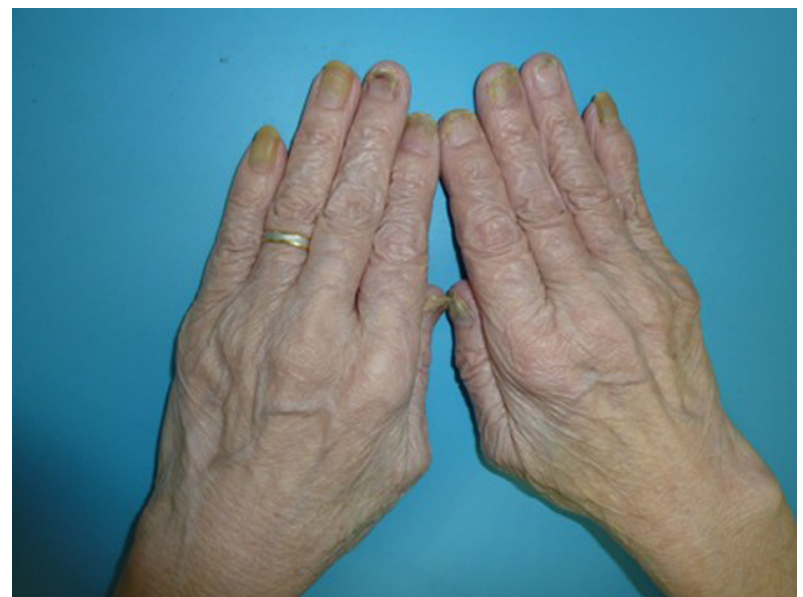

Figure 3 Reversal of yellowish fingernails after treatment of malignancies or withdrawal of associated drugs. 


\section{BMJ Case Reports}

\section{Learning points}

- Diagnosis of YNS requires two of the following three criteria: yellowish nails, lymphoedema and a respiratory manifestation.

- Yellow nails, lymphoedema and lung involvement are simultaneously present in only a quarter of patients.

- YNS is associated with connective tissue diseases, malignancies, and thiol-compound drugs.

- Reversal of nail colour may be observed after treatment of malignancies or withdrawal of associated drugs.
Competing interests None.

Patient consent Obtained.

\section{REFERENCES}

1. Samman PD, White WF. The "Yellow Nail" syndrome. Br J Dermatol 1964;76:153-7.

2. Emerson PA. Yellow nails, lymphoedema, and pleural effusions. Thorax 1966;21:247-53.

3. Hiller $\mathbf{E}$, Rosenow EC 3rd, Olsen AM. Pulmonary manifestations of the yellow nail syndrome. Chest 1972;61:452-8.

4. Maldonado F, Ryu JH. Yellow nail syndrome. Curr Opin Pulm Med 2009;15:371-5.

5. Mattingly PC, Bossingham DH. Yellow nail syndrome in rheumatoid arthritis: report of three cases. Ann Rheum Dis 1979;38:475-8.

This pdf has been created automatically from the final edited text and images.

Copyright 2012 BMJ Publishing Group. All rights reserved. For permission to reuse any of this content visit http://group.bmj.com/group/rights-licensing/permissions.

BMJ Case Report Fellows may re-use this article for personal use and teaching without any further permission.

Please cite this article as follows (you will need to access the article online to obtain the date of publication).

Taki H, Tobe K. Yellow nail syndrome associated with rheumatoid arthritis, thiol-compound therapy and early gastric cancer. BMJ Case Reports 2012; 10.1136/bcr.11.2011.5183, Published XXX

Become a Fellow of BMJ Case Reports today and you can:

- Submit as many cases as you like

- Enjoy fast sympathetic peer review and rapid publication of accepted articles

- Access all the published articles

- Re-use any of the published material for personal use and teaching without further permission

For information on Institutional Fellowships contact consortiasales@bmjgroup.com

Visit casereports.bmj.com for more articles like this and to become a Fellow

Keep up to date with all published cases by signing up for an alert (all we need is your email address) http://casereports.bmj.com/cgi/alerts/etoc 